\title{
Macrocycle Synthesis by Chloride-Templated Amide Bond Formation
}

\author{
Vicente Martí-Centelles,* M. Isabel Burguete, and Santiago V. Luis* \\ Departamento de Química Inorgánica y Orgánica, Universitat Jaume I, Avenida de Vicent Sos Baynat s/n, 12071 Castellón, Spain
}

Supporting Information

ABSTRACT: A new family of pseudopeptidic macrocyclic compounds has been prepared involving an anion-templated amide bond formation reaction at the macrocyclization step. Chloride anion was found to be the most efficient template in the macrocyclization process, producing improved macrocyclization yields with regard to the nontemplated reaction. The data suggest a kinetic effect of the chloride template, providing an appropriate folded conformation of the openchain precursor and reducing the energy barrier for the formation of the macrocyclic product.

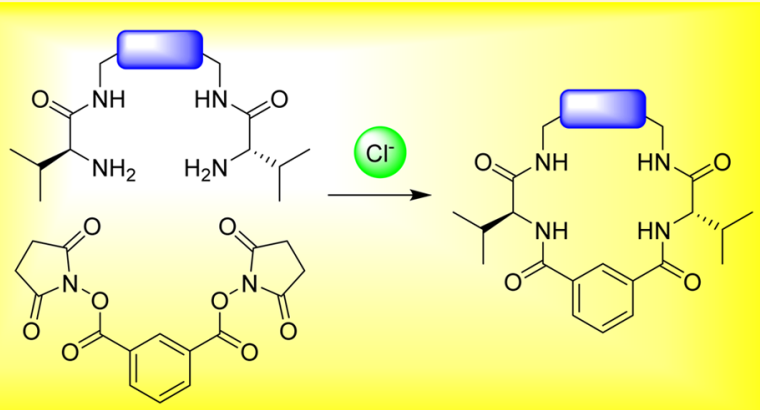

$\mathrm{T}$ he central role of anions in environmental science, biology, and medicine has motivated chemists to develop selective anion receptors. Many of these receptors are macrocycles as long as the high level of favorable preorganization allows achieving an improved selectivity and stronger interactions. $^{1-15}$ The synthesis of macrocyclic compounds is challenging and usually requires an important synthetic effort in the final macrocyclization step, which is in many instances the yield limiting step. ${ }^{16}$ In this regard, the use of anions as templates is a promising synthetic methodology to achieve efficient macrocyclization processes; however, this approach has not been fully explored in many of these processes. ${ }^{16-18}$

Some pioneering examples in this context include the use of anions as kinetic templates. Alcalde and co-workers described the chloride- and bromide-templated macrocyclization reactions through $S_{N} 2$ reactions at the macrocyclization step, ${ }^{19,20}$ and Luis and co-workers reported the anion-templated macrocyclization reactions of $\mathrm{C}_{2}$-symmetric pseudopeptides involving $\mathrm{S}_{\mathrm{N}} 2$ and Schiff reactions. ${ }^{21-23}$ Similarly, Meshcheryakov et al. observed a crucial template effect of the chloride anion in the preparation of tetrameric urea macrocycles: it was not possible to isolate the macrocyclic product in the absence of chloride. ${ }^{24}$ In the same way, Katev and co-workers proved the templating effect of anions in some macrocyclization reactions involving amide bond formation. ${ }^{25}$ In addition, Jurczak and co-workers prepared macrocyclic structures using the chloride anion as a template. ${ }^{26}$ The key templating role of anions has been reported by Beer and co-workers in the synthesis of interlocked structures. In this case, the templating anions are essential for the preparation of isophthalamide-based rotaxane structures in that the chloride anion provides a higher rotaxanation yield. ${ }^{27,28}$

Herein, we report the preparation of a novel family of macrocyclic isophthalamide-containing pseudopeptidic compounds in a macrocyclization process involving two consecutive amide bond formation reactions. The reaction involves a pseudopeptidic compound $\mathbf{1}^{21,29-31}$ and the isophthaloyl-Nhydroxysuccinimide-activated ester $2^{32}$ and provides access to new isophthalamide pseudopeptidic macrocycles. This new family of compounds has been designed with consideration to the chemical structure of the pseudopeptidic macrocycles (A) previously studied by us. ${ }^{21,29-31}$ This design involved the use of the isophthalamide motif instead of the $m$-xylylenediamine motif, using amide linkages to bond all building blocks (Scheme 1). This design provides macrocycles with four potentially

Scheme 1. Isophthalamide-Containing Macrocyclic Pseudopeptidic Compounds 3 and the $m$-Xylylenediamine Analogues A As Previously Described
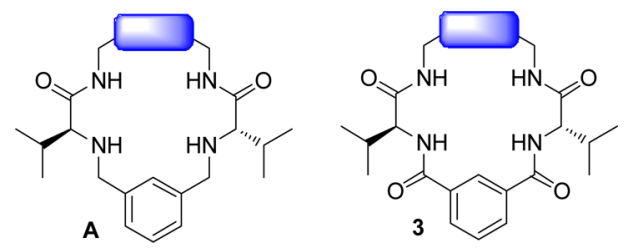

convergent amide groups that favor interaction with anions under neutral conditions. This interaction can introduce novel properties to the macrocycles such as the formation of supramolecular ordered structures, molecular recognition, and catalysis. $^{33}$ In this context, to obtain an efficient macrocyclization yield, we have explored the kinetic templating role of anions in the macrocyclization reaction involving amide bond formation through the analysis of the macrocyclization yield in $\mathrm{CH}_{2} \mathrm{Cl}_{2}$. Similar effects are also present in $\mathrm{CDCl}_{3}$ as revealed by the study of the corresponding macrocyclization reaction kinetics.

Received: November 23, 2015 
The synthesis of the target macrocyclic compounds 3 and $\mathbf{4}$ was envisaged by the reaction of the pseudopeptidic compound $\mathbf{1}$ with isophthaloyl- $\mathrm{N}$-hydroxysuccinimide-activated ester $2^{32}$ in both the absence and presence of templating anions in $\mathrm{CH}_{2} \mathrm{Cl}_{2}$ (Scheme 2).

Scheme 2. Isophthalamide-Containing Macrocyclic Pseudopeptidic Compounds 3 and 4 Prepared in This Work (TBA = tetrabutyl ammonium)

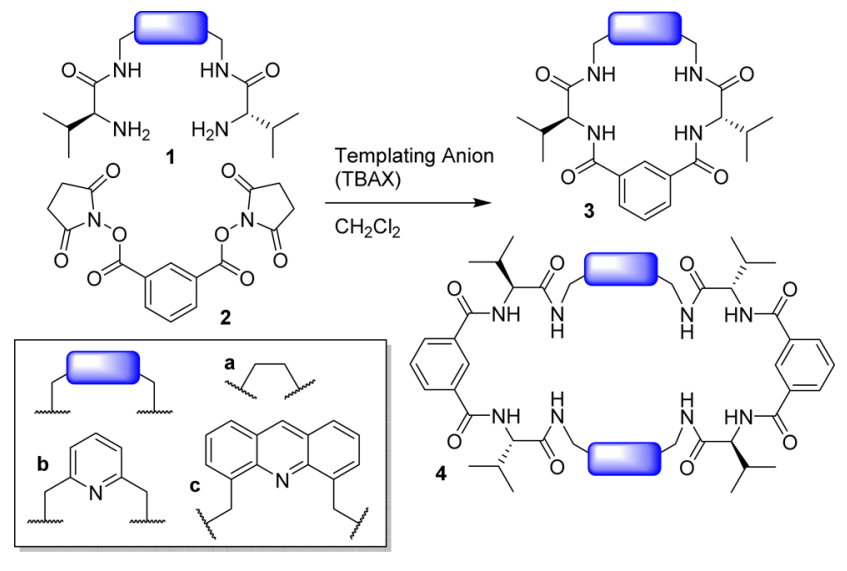

Initially, a significant effect of the nature of the spacer on the macrocyclization yield for the preparation of macrocycles $3 a-c$ at a concentration of $10 \mathrm{mM}$ was observed (Table 1). For

Table 1. Isolated Yields for the Macrocyclization Reaction in the Presence and Absence of Templating Anion (Added as Tetrabutyl Ammonium Salt) in $\mathrm{CH}_{2} \mathrm{Cl}_{2}$

\begin{tabular}{|c|c|c|c|}
\hline reaction conditions & 1a & $1 b$ & $1 \mathrm{c}$ \\
\hline $1 \mathrm{mM}$, no template ${ }^{a}$ & $\begin{array}{l}6 \%[1+1] \mathbf{3 a} \\
18 \%[2+2] \mathbf{4 a}\end{array}$ & $45 \% \mathbf{3 b}$ & $18 \% 3 \mathrm{c}$ \\
\hline $10 \mathrm{mM}$, no template ${ }^{b}$ & $\begin{array}{l}4 \%[1+1] \mathbf{3 a} \\
9 \%[2+2] \mathbf{4 a}\end{array}$ & $17 \% \mathbf{3 b}$ & $3 \% 3 c$ \\
\hline $10 \mathrm{mM}, \mathrm{TBACl}^{b}$ & $\begin{array}{l}17 \%[1+1] \mathbf{3 a} \\
17 \%[2+2] \mathbf{4 a}\end{array}$ & $51 \% 3 \mathbf{b}^{c}$ & $38 \% 3 \mathrm{c}$ \\
\hline $10 \mathrm{mM}, \mathrm{TBABr}^{b}$ & $\begin{array}{l}11 \%[1+1] \mathbf{3 a} \\
15 \%[2+2] \mathbf{4 a}\end{array}$ & $31 \% \mathbf{3 b}$ & $18 \% 3 c$ \\
\hline $10 \mathrm{mM}$, TBAI $^{b}$ & $\begin{array}{l}6 \%[1+1] 3 \mathbf{a} \\
9 \%[2+2] \mathbf{4 a}\end{array}$ & $27 \% \mathbf{3 b}$ & $5 \% 3 c$ \\
\hline
\end{tabular}

${ }^{a} 40{ }^{\circ} \mathrm{C}, 7$ days. ${ }^{b} \mathrm{Rt}, 2$ days. ${ }^{c}$ Using 10 equiv of TBACl $(100 \mathrm{mM})$ and $1 \mathbf{b}(10 \mathrm{mM})$, the $[1+1]$ macrocyclic product $3 \mathbf{b}$ was isolated in $68 \%$ yield.

compound 1a, with a flexible ethylene diamine aliphatic spacer, both $[1+1](3 a)$ and $[2+2](4 a)$ macrocyclic products were isolated in the absence of any added template in $4 \%$ and $9 \%$ yields, respectively, after chromatographic purification. In contrast, for the more favorable preorganized open-chain compounds $\mathbf{1 b}$ (pyridine) and $\mathbf{1 c}$ (acridine), only the $[1+1]$ macrocyclic product was isolated in $17 \%$ and $3 \%$ yields, respectively. These yields were enhanced using 1 equiv of templating anion $\left(\mathrm{Cl}^{-}, \mathrm{Br}^{-}\right.$, and $\left.\mathrm{I}^{-}\right)$in the corresponding macrocyclization reactions, even when the concentration of the substrates was appreciably increased (10-fold concentration increase, Table 1). This observation suggests that the intramolecular macrocyclization reaction is favored over the intermolecular oligomerization processes ${ }^{34,35}$ in the presence of the templating anion, in particular the $[1+1]$ process. $^{21,22,36,37}$
The observed templating effect follows the order $\mathrm{Cl}^{-}>\mathrm{Br}^{-}>$ $\mathrm{I}^{-}$, which suggests a more favorable effect of the chloride anion on the reaction intermediates of the process yielding the macrocyclic structure. This is a reflection of the stronger coordination strength of chloride due to its smaller radius and stronger Coulomb attraction due to the shorter distance to the $\mathrm{NH}$ groups. We isolated the macrocycle $3 \mathrm{~b}$ in $68 \%$ yield using 10 equiv of chloride, instead of the $51 \%$ yield obtained in the presence of only 1 equiv of chloride. All of the macrocyclic compounds were obtained as pure compounds and were fully characterized by NMR and HRMS. Appropriate crystals for Xray diffraction could be obtained only for compound 3a. The corresponding structure is presented in the Supporting Information.

The kinetic role of chloride was then evaluated by following the ${ }^{1} \mathrm{H}$ NMR evolution with time of the macrocyclization of $\mathbf{1 b}$ in the presence of 1 and 10 equiv of chloride in $\mathrm{CDCl}_{3}$ (Figure 1). The use of $\mathrm{CDCl}_{3}$ rather than $\mathrm{CD}_{2} \mathrm{Cl}_{2}$ facilitated the

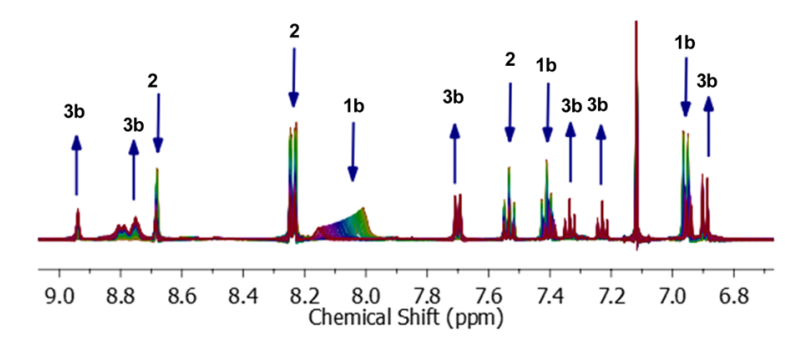

Figure 1. Reaction kinetics of the macrocyclization reaction of $\mathbf{1 b}$ in the presence of 10 equiv of $\mathrm{TBACl}$. The product formation was determined by ${ }^{1} \mathrm{H}$ NMR $\left(30{ }^{\circ} \mathrm{C}, \mathrm{CDCl}_{3}, 10 \mathrm{mM}\right)$. Upward arrows indicate macrocycle $\mathbf{3 b}$ formation, and downward arrows indicate disappearance of open-chain precursor $\mathbf{1 b}$ and isophthaloyl- $N$ hydroxysuccinimide-activated ester 2 .

analysis of the complex spectra obtained and the monitoring of most of the peaks of interest. In Figure 1, upward arrows indicate macrocycle $\mathbf{3 b}$ formation and downward arrows indicate disappearance of open-chain precursor $\mathbf{1 b}$ and isophthaloyl- $N$-hydroxysuccinimide-activated ester 2 . The results show a clear increase in the formation rate of macrocycle $3 \mathbf{b}$ with the change in concentration of chloride anion from 10 $\mathrm{mM}$ ( 1 equiv) to $100 \mathrm{mM}$ ( 10 equiv), confirming the kinetic role of this anion in the process (Figure 2). ${ }^{38}$ The good yields obtained in the presence of chloride could not be achieved by

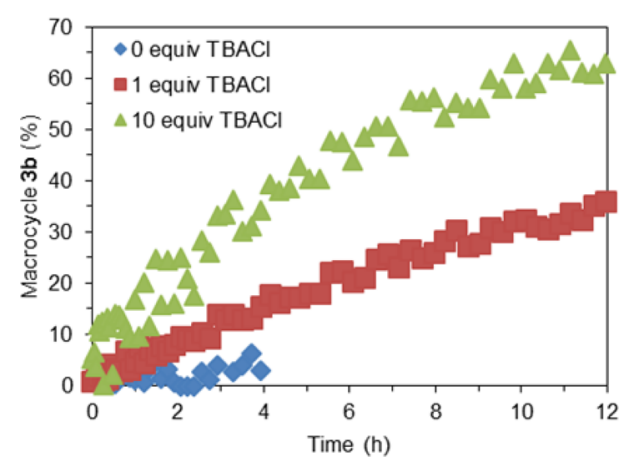

Figure 2. Reaction kinetics of the macrocyclization reaction of $\mathbf{1 b}$ in the presence of 1 and 10 equiv of $\mathrm{TBACl}$ to form macrocycle $3 \mathbf{b}$. The product formation was determined by ${ }^{1} \mathrm{H}$ NMR $\left(30{ }^{\circ} \mathrm{C}, \mathrm{CDCl}_{3}, 10\right.$ $\mathrm{mM})$. 
reducing the concentration of the reactants from 10 to $1 \mathrm{mM}$ in the absence of any templating anion, highlighting the synthetic benefits of the use of templates in the preparation of macrocyclic structures. ${ }^{39,40}$

The proposed macrocyclization process comprises two steps: the first step yields the open-chain macrocyclic precursor $\mathbf{5 b}$, and the second step yields the macrocycle $\mathbf{3 b}$ (Figure 3).

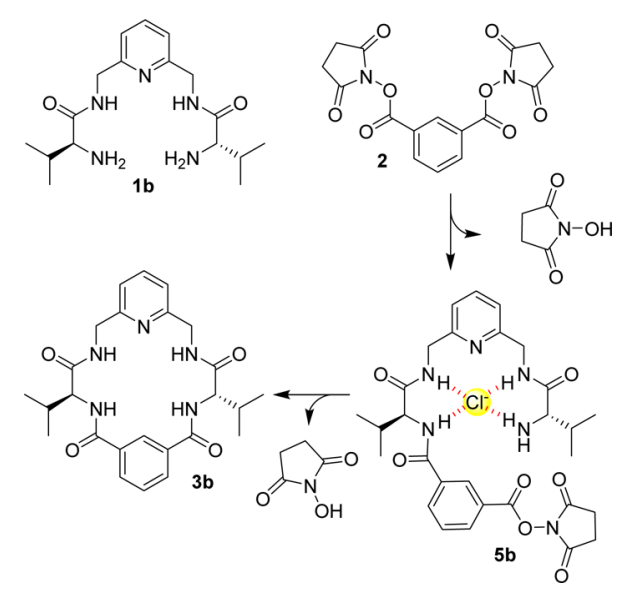

Figure 3. Proposed role of the chloride-templating anion in the macrocyclization reaction of $\mathbf{1 b}$ with $\mathbf{2}$.

Focusing on the macrocyclization step, we propose that the chloride anion interacts with $\mathbf{5} \mathbf{b}$ by hydrogen bonding to the three amide groups, which are oriented in a convergent arrangement, and one hydrogen atom of the amine, which transforms into an amide group, as suggested by preliminary computational calculations using Gaussian $09^{41}$ at the PM6 semiempirical level of theory. This provides a favorable preorganization of the linear precursor, thereby reducing the unfavorable activation entropy of the macrocyclization. Therefore, the chloride anion can play a crucial role, not only by providing an appropriately folded conformation of $\mathbf{5 b}$ but also by favoring the formation of the $[1+1]$ macrocyclic product by reducing the energy barrier of the macrocyclization reaction through the strong interaction with the corresponding transition states. In this regard, the chloride-reaction intermediate complex (5b) could be unambiguously detected by ESI-MS in the macrocyclization reaction mixture (Figure 4).

\section{CONCLUSIONS}

We have successfully prepared a new family of pseudopeptidic macrocycles through an efficient chloride-templated macro-

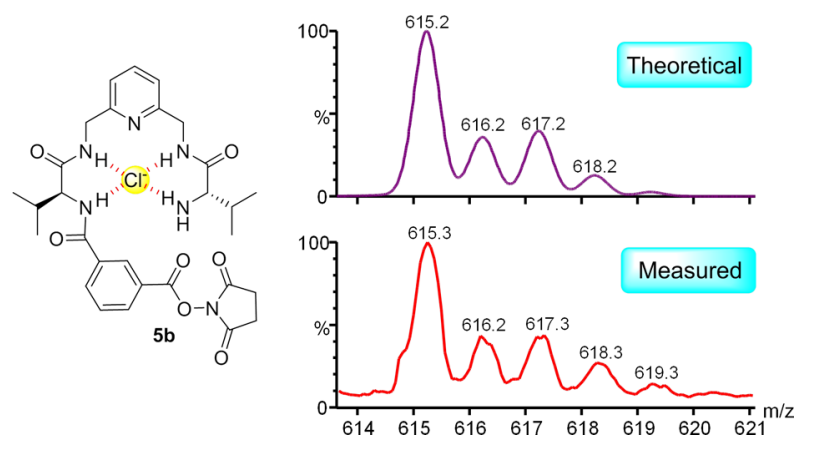

Figure 4. Proposed structure of the chloride complex of the reaction intermediate $\mathbf{5 b}$ detected by ESI-MS. cyclization reaction involving an amide bond formation. Our results demonstrate that both the presence of structural factors on the pseudopeptidic spacer, which could facilitate the preorganization of the open-chain intermediate, and the presence of templating anions, in particular the chloride anion, play a key role in favoring the macrocyclization process to selectively achieve the $[1+1]$ macrocyclization reaction. The results obtained suggest that an efficient templating role of the chloride anion results in the corresponding $[1+1]$ macrocyclization process being kinetically facilitated. The synthetic utility of anionic templates in amide bond formation-based macrocyclization processes can be even greater than that observed in the case of $S_{N} 2$ reactions; for example, in the last case the alkylating agents provide halide anions, allowing an intrinsic template effect to occur. ${ }^{21-23}$ Interestingly, the use of this template effect results in a 10 -fold increase in the concentration of the substrates without any negative effect on the macrocyclization yield.

\section{EXPERIMENTAL SECTION}

NMR experiments were carried out at $500 \mathrm{MHz}$ for ${ }^{1} \mathrm{H}$ and $125 \mathrm{MHz}$ for ${ }^{13} \mathrm{C}$. Chemical shifts are reported in ppm from tetramethylsilane with the solvent resonance as the internal standard. FT-IR spectra were recorded using an ATR adapter. Microanalyses were performed on an elemental analyzer equipped with an oxygen module. Mass spectra were recorded with a Q-TOF instrument. Rotatory power was determined with a digital polarimeter $(\mathrm{Na}: 589 \mathrm{~nm})$. Melting points were measured using a standard apparatus and are uncorrected.

Synthesis. Isophthaloyl- $N$-hydroxysuccinimide-activated ester $\mathbf{2}^{32}$ and pseudopeptidic compounds $\mathbf{1 a},{ }^{31} \mathbf{1} \mathbf{b},{ }^{21}$ and $\mathbf{1} \mathbf{c}^{29}$ were prepared following literature procedures. The isolated macrocyclic compounds 3 and 4 were found to have a limited solubility in $\mathrm{CDCl}_{3}$ in the concentrations required for the NMR spectroscopic characterization; DMSO- $d_{6}$ was found to dissolve the obtained macrocyclic products in the concentrations required.

General Macrocyclization Reaction Conditions. To prepare pseudopeptidic macrocycle $3 \mathbf{b}$, open-chain precursor $1 \mathbf{b}(50.0 \mathrm{mg}$, $0.149 \mathrm{mmol})$ and TBACl $(41.4 \mathrm{mg}, 0.149 \mathrm{mmol})$ were dissolved in dry $\mathrm{CH}_{2} \mathrm{Cl}_{2}(10 \mathrm{~mL})$ and then a solution of activated isophthalic acid 2 ( $53.7 \mathrm{mg}, 0.149 \mathrm{mmol})$ in dry $\mathrm{CH}_{2} \mathrm{Cl}_{2}(4.9 \mathrm{~mL})$ was added to the reaction mixture to achieve a $10 \mathrm{mM}$ equimolar mixture of both reactants and the template anion. The reaction mixture was stirred at room temperature under a nitrogen atmosphere for 2 days. At this time, the solvent was removed in vacuo, and the crude product was purified by silica gel column chromatography using a $\mathrm{CH}_{2} \mathrm{Cl}_{2} / \mathrm{MeOH}$ gradient (from 0 to $10 \%$ ) to yield the expected macrocyclic product $3 \mathrm{~b}$ as a white solid ( $35.3 \mathrm{mg}, 51 \%$ yield). ${ }^{1} \mathrm{H}$ NMR $(500 \mathrm{MHz}$, DMSO$\left.d_{6}\right): \delta 0.81(6 \mathrm{H}, \mathrm{d}, J=6.7 \mathrm{~Hz}), 0.90(6 \mathrm{H}, \mathrm{d}, J=6.8 \mathrm{~Hz}), 2.04-2.12$ $(2 \mathrm{H}, \mathrm{m}), 4.36-4.49(6 \mathrm{H}, \mathrm{m}), 7.37(2 \mathrm{H}, \mathrm{d}, J=7.7 \mathrm{~Hz}), 7.56(1 \mathrm{H}, \mathrm{t}, J=$ $7.7 \mathrm{~Hz}), 7.77-7.80(3 \mathrm{H}, \mathrm{m}), 7.91(2 \mathrm{H}, \mathrm{t}, J=4.6 \mathrm{~Hz}), 8.13(1 \mathrm{H}, \mathrm{t}, J=$ $1.5 \mathrm{~Hz}), 8.63(2 \mathrm{H}, \mathrm{d}, J=10.0 \mathrm{~Hz}) .{ }^{13} \mathrm{C}$ NMR $\left(126 \mathrm{MHz}, \mathrm{DMSO}-d_{6}\right)$ : $\delta 18.5,19.3,25.2,30.8,44.7,59.7,122.0,126.3,128.8,130.0,135.2$, 137.7, 156.1, 167.4, 170.3. IR (ATR): 3510, 3304, 3273, 3082, 3065, $2962,2927,2872,1668,1636,1624,1599,1533,1455,1305 \mathrm{~cm}^{-1} . \mathrm{Mp}$ $>300{ }^{\circ} \mathrm{C}$ dec. $[\alpha]_{\mathrm{D}}{ }^{25}=-191.00(c=0.01$ in DMSO $)$. ESI TOF HRMS $m / z$ : found $466.2459[\mathrm{M}+\mathrm{H}]^{+}$, calcd for $\left[\mathrm{C}_{25} \mathrm{H}_{31} \mathrm{~N}_{5} \mathrm{O}_{4}+\mathrm{H}\right]^{+}$ 466.2454. Anal. Calcd for $\mathrm{C}_{25} \mathrm{H}_{31} \mathrm{~N}_{5} \mathrm{O}_{4}$ : C, 64.50; H, 6.71; N, 15.04 . Found: C, 64.54; H, 6.70; N, 14.72 .

Compound $3 \mathrm{c}$ was prepared using the general macrocyclization reaction conditions: $1 \mathrm{c}(150.0 \mathrm{mg}, 0.3444 \mathrm{mmol}), \mathrm{TBACl}(95.7 \mathrm{mg}$, $0.3444 \mathrm{mmol})$, and $2(124.1 \mathrm{mg}, 0.3444 \mathrm{mmol})$ in dry $\mathrm{CH}_{2} \mathrm{Cl}_{2}(34$ $\mathrm{mL})$. Pale yellow solid, $38 \%$ yield $(73.7 \mathrm{mg})$ after silica gel column chromatography using a $\mathrm{CH}_{2} \mathrm{Cl}_{2} / \mathrm{MeOH}$ gradient (from 0 to $\left.10 \%\right) .{ }^{1} \mathrm{H}$ NMR (500 MHz, DMSO- $\left.d_{6}\right): \delta 0.77(6 \mathrm{H}, \mathrm{d}, J=6.8 \mathrm{~Hz}), 0.89(6 \mathrm{H}, \mathrm{d}$, $J=6.8 \mathrm{~Hz}), 2.10-2.20(2 \mathrm{H}, \mathrm{m}), 4.52(2 \mathrm{H}, \mathrm{dd}, J=10.0,5.9 \mathrm{~Hz}), 5.15$ $(2 \mathrm{H}, \mathrm{dd}, J=13.4,3.5 \mathrm{~Hz}), 5.50(2 \mathrm{H}, \mathrm{dd}, J=13.4,7.9 \mathrm{~Hz}), 7.49(1 \mathrm{H}, \mathrm{t}$, $J=7.7 \mathrm{~Hz}), 7.64(2 \mathrm{H}, \mathrm{dd}, J=8.1,7.2 \mathrm{~Hz}), 7.71(2 \mathrm{H}, \mathrm{dd}, J=7.6,1.2$ 
$\mathrm{Hz}), 8.00-8.07$ (4H, m), $8.13(2 \mathrm{H}, \mathrm{d}, J=8.1 \mathrm{~Hz}), 8.21(1 \mathrm{H}, \mathrm{s}), 8.28$ $(\mathrm{d}, J=10.0 \mathrm{~Hz}, 2 \mathrm{H}), 9.14(1 \mathrm{H}, \mathrm{s}) .{ }^{13} \mathrm{C}$ NMR $\left(126 \mathrm{MHz}, \mathrm{DMSO}-d_{6}\right)$ : $\delta 17.8,19.3,31.3,37.0,58.8,125.8,126.0,126.4,127.9,128.6,129.5$, 131.3, 135.4, 137.0, 137.1, 146.0, 167.8, 170.8. IR (ATR): 3322, 3268, $3149,3051,2966,2907,2871,1674,1631,1531,1263 \mathrm{~cm}^{-1}$. Mp >300 ${ }^{\circ} \mathrm{C}$ dec. $[\alpha]_{\mathrm{D}}{ }^{25}=-85.26(c=0.01$ in DMSO). ESI TOF HRMS $m / z$ : found $566.2772[\mathrm{M}+\mathrm{H}]^{+}$, calcd for $\left[\mathrm{C}_{33} \mathrm{H}_{35} \mathrm{~N}_{5} \mathrm{O}_{4}+\mathrm{H}\right]^{+} 566.2767$. Anal. Calcd for $\mathrm{C}_{33} \mathrm{H}_{35} \mathrm{~N}_{5} \mathrm{O}_{4}$ : C, 70.07; H, 6.24; N, 12.38. Found: $\mathrm{C}$, 69.92; H, 6.22; N, 12.10 .

Compound 3a was prepared using the general macrocyclization reaction conditions: $1 \mathrm{a}(200.0 \mathrm{mg}, 0.7741 \mathrm{mmol}), \mathrm{TBACl}(215.1 \mathrm{mg}$, $0.7741 \mathrm{mmol})$, and $2(278.9 \mathrm{mg}, 0.7741 \mathrm{mmol})$ in dry $\mathrm{CH}_{2} \mathrm{Cl}_{2}(77$ $\mathrm{mL})$. White solid, $17 \%$ yield $(52.1 \mathrm{mg})$ after silica gel column chromatography using a $\mathrm{CH}_{2} \mathrm{Cl}_{2} / \mathrm{MeOH}$ gradient (from 0 to $10 \%$ ). ${ }^{1} \mathrm{H}$ NMR (500 MHz, DMSO- $\left.d_{6}\right): \delta 0.88(6 \mathrm{H}, \mathrm{d}, J=6.6 \mathrm{~Hz}), 0.93(6 \mathrm{H}, \mathrm{d}$, $J=6.7 \mathrm{~Hz}), 1.95-2.08(2 \mathrm{H}, \mathrm{m}), 3.34(4 \mathrm{H}, \mathrm{s}), 4.21(2 \mathrm{H}, \mathrm{dd}, J=7.9$, $10.2 \mathrm{~Hz}), 7.57(1 \mathrm{H}, \mathrm{t}, J=7.6 \mathrm{~Hz}), 7.70(2 \mathrm{H}, \mathrm{s}), 7.77(2 \mathrm{H}, \mathrm{dd}, J=0.9$, $7.6 \mathrm{~Hz}), 8.10(1 \mathrm{H}, \mathrm{s}), 8.23(2 \mathrm{H}, \mathrm{d}, J=10.5 \mathrm{~Hz}) .{ }^{13} \mathrm{C}$ NMR $(126 \mathrm{MHz}$, DMSO- $\left.d_{6}\right): \delta 18.7,19.6,30.3,38.4,61.2,129.09,129.13,131.0,135.6$, 168.0, 171.4. IR (ATR): 3351, 3309, 3115, 3069, 2937, 2883, 1685, $1674,1664,1633,1620,1603,1519,1463,1280 \mathrm{~cm}^{-1} . \mathrm{Mp}>300{ }^{\circ} \mathrm{C}$ dec. $[\alpha]_{\mathrm{D}}{ }^{25}=-234.44(c=0.01$ in DMSO $)$. ESI TOF HRMS $m / z$ : found $389.2189[\mathrm{M}+\mathrm{H}]^{+}$, calcd for $\left[\mathrm{C}_{20} \mathrm{H}_{28} \mathrm{~N}_{4} \mathrm{O}_{4}+\mathrm{H}\right]^{+} 389.2189$. Anal. Calcd for $\mathrm{C}_{20} \mathrm{H}_{28} \mathrm{~N}_{4} \mathrm{O}_{4}$ : C, 61.84; H, 7.27; N, 14.42. Found: C, 62.15; H, 7.26; N, 14.15.

From the previous reaction, macrocyclic compound $4 \mathbf{a}$ was isolated in $17 \%$ yield $(51.7 \mathrm{mg})$ in the column chromatographic purification as a white solid. ${ }^{1} \mathrm{H}$ NMR $\left(500 \mathrm{MHz}, \mathrm{DMSO}-d_{6}\right): \delta 0.78-0.96(12 \mathrm{H}$, $\mathrm{m}), 2.03-2.15(2 \mathrm{H}, \mathrm{m}), 3.05-3.15(2 \mathrm{H}, \mathrm{m}), 3.18-3.28(2 \mathrm{H}, \mathrm{m})$, $4.19-4.23(2 \mathrm{H}, \mathrm{m}), 7.51(1 \mathrm{H}, \mathrm{t}, J=7.7 \mathrm{~Hz}), 7.94(2 \mathrm{H}, \mathrm{dd}, J=7.7,1.4$ $\mathrm{Hz}), 8.06(2 \mathrm{H}, \mathrm{s}), 8.24(1 \mathrm{H}, \mathrm{s}), 8.43(2 \mathrm{H}, \mathrm{d}, J=8.5 \mathrm{~Hz}) .{ }^{13} \mathrm{C} \mathrm{NMR}$ $\left(126 \mathrm{MHz}, \mathrm{DMSO}-d_{6}\right): \delta 18.8,19.3,29.7,38.2,59.4,126.5,128.1$, 130.2, 134.4, 166.4, 171.2. IR (ATR): 3280, 3082, 2965, 2938, 2873, $1635,1525,1249 \mathrm{~cm}^{-1}$. Mp $>300{ }^{\circ} \mathrm{C}$ dec. $[\alpha]_{\mathrm{D}}{ }^{25}=+38.70(c=0.01$ in DMSO). ESI TOF HRMS $m / z$ : found $777.4285[\mathrm{M}+\mathrm{H}]^{+}$, calcd for $\left[\mathrm{C}_{40} \mathrm{H}_{56} \mathrm{~N}_{8} \mathrm{O}_{8}+\mathrm{H}\right]^{+}$777.4299. Anal. Calcd for $\mathrm{C}_{40} \mathrm{H}_{56} \mathrm{~N}_{8} \mathrm{O}_{8} \cdot \mathrm{H}_{2} \mathrm{O}: \mathrm{C}$, 60.44; H, 7.35; N, 14.10. Found: C, 60.63; H, 7.32; N, 13.74.

${ }^{1} \mathrm{H}$ NMR Macrocyclization Kinetic Analysis. Bis(amino amide) $1 \mathbf{b}$ ( 1 equiv), TBACl ( 0,1 , or 10 equiv), and tetrakis(trimethylsilyl)silane ( 0.1 equiv) were dissolved in $\mathrm{CDCl}_{3}$. Then, activated isophthalic acid 2 ( 1 equiv) in $\mathrm{CDCl}_{3}$ was added to the reaction mixture to achieve a final concentration of $10 \mathrm{mM}$. The reaction mixture was transferred quantitatively to an NMR tube, and a ${ }^{1} \mathrm{H}$ NMR spectrum was acquired at different reaction times for at least $12 \mathrm{~h}$ at $30^{\circ} \mathrm{C}$. The quantification of the signals of the product of the macrocyclization reaction and the signals corresponding to the starting reactants was carried out using the internal standard's integral, and its chemical shift was referenced to $0 \mathrm{ppm}$.

X-ray Crystallography. Single crystals of $3 \mathbf{a}$ were obtained by slow diffusion of a layer of water on a solution of $3 \mathbf{a}$ in DMSO. A suitable crystal was selected and measured on a single crystal X-ray diffractometer. The crystal was kept at $200.0 \mathrm{~K}$ during data collection. Using Olex2, ${ }^{42}$ the structure was solved with the ShelXS $2014^{43}$ structure solution program using Direct Methods and refined with the ShelXL $2014^{43}$ refinement package using Least Squares minimization.

Crystal data for $3 \mathrm{a} \mathrm{C}_{20} \mathrm{H}_{28} \mathrm{~N}_{4} \mathrm{O}_{4} \cdot 2\left(\mathrm{C}_{2} \mathrm{H}_{6} \mathrm{OS}\right)(M=544.72 \mathrm{~g} / \mathrm{mol})$ : monoclinic, space group $P 2_{1}$ (No. 4), $a=9.61329(18) \AA, b=$ 9.54113(15) $\AA, c=16.1853(3) \AA ̊, \beta=96.3113(18)^{\circ}, V=1475.55(5)$ $\AA^{3}, Z=2, T=200.0 \mathrm{~K}, \mu(\mathrm{CuK} \alpha)=1.984 \mathrm{~mm}^{-1}, D_{\text {calc }}=1.226 \mathrm{~g} / \mathrm{cm}^{3}$, 26325 reflections measured $(9.256 \leq 2 \Theta \leq 145.628)$, 5814 unique $\left(R_{\text {int }}=0.0526, R_{\sigma}=0.0256\right)$, which were used in all calculations. The final $R_{1}=0.0438(I>2 \sigma(I))$ and $w R_{2}=0.1231$ (all data) (CCDC no. 1452165).

Mass Spectrometry. Mass spectra were recorded on a triple quadrupole mass spectrometer by electrospray negative mode (ES-). Nitrogen was used as both the desolvation gas and the nebulizing gas at a flow of 425 and $100 \mathrm{~L} \mathrm{~h}^{-1}$, respectively. The temperature of the source block was set to $120^{\circ} \mathrm{C}$, and the desolvation temperature was set to $150{ }^{\circ} \mathrm{C}$. A capillary voltage of 3.5 and $3.3 \mathrm{kV}$ was used in the positive and negative scan modes, respectively. The cone voltage was set to $20 \mathrm{~V}$. The reaction was set up using equimolar amounts of pseudopeptide $\mathbf{1 b}$, isophthalamide-activated compound $\mathbf{2}$, and $\mathrm{TBACl}$ to obtain a $10 \mathrm{mM}$ concentration of each reactant in $\mathrm{CH}_{2} \mathrm{Cl}_{2}$ at rt. Five minutes after beginning the reaction, a sample of the reaction mixture was taken and diluted 100 times with $\mathrm{MeOH}$, and then the resulting solution was infused via a syringe pump directly connected to the ESI source at a flow rate of $12 \mu \mathrm{L} \mathrm{min}$. The observed isotopic pattern of the intermediate $\mathbf{5 b}$ perfectly matched the theoretical isotope pattern calculated from its elemental composition.

\section{ASSOCIATED CONTENT}

\section{S Supporting Information}

The Supporting Information is available free of charge on the ACS Publications website at DOI: 10.1021/acs.joc.5b02676.

${ }^{1} \mathrm{H}$ and ${ }^{13} \mathrm{C}$ NMR of the new compounds and NMR kinetic experiments (PDF)

Solid state structure of macrocyclic compound $3 \mathbf{a}$ as determined by X-ray crystallography (CCDC no. 1452165) (CIF)

\section{AUTHOR INFORMATION}

\section{Corresponding Authors}

*E-mail: luiss@uji.es.

*E-mail: martiv@uji.es.

\section{Notes}

The authors declare no competing financial interests.

\section{ACKNOWLEDGMENTS}

This work was supported by the Spanish Ministry of Science and Innovation (CTQ2012-38543-C03) and Generalitat Valenciana (PROMETEO/2012/020). V.M.-C. thanks Generalitat Valenciana for a postdoctoral fellowship (APOSTD/ 2013/041). The support of the SCIC for the different instrumental techniques and the Servei d'Informatica for providing the computational facilities at Universitat Jaume I is acknowledged.

\section{REFERENCES}

(1) Sessler, J. L.; Gale, P. A.; Cho, W.-S. Anion Receptor Chemistry; RSC: Cambridge, U.K., 2006.

(2) Bianchi, A.; Bowman-James, K.; Garcia-España, E. Anion Coordination Chemistry; Wiley-VCH: Weinheim, Germany, 2011.

(3) Beer, P. D.; Gale, P. A. Angew. Chem., Int. Ed. 2001, 40, 486-516.

(4) Evans, N. H.; Beer, P. D. Angew. Chem., Int. Ed. 2014, 53, 1171611754 .

(5) Spence, G. T.; Beer, P. D. Acc. Chem. Res. 2013, 46, 571-586.

(6) Langton, M. J.; Beer, P. D. Acc. Chem. Res. 2014, 47, 1935-1949.

(7) Gale, P. A.; Busschaert, N.; Haynes, C. J. E.; Karagiannidis, L. E.; Kirby, I. L. Chem. Soc. Rev. 2014, 43, 205-241.

(8) Kubik, S. Chem. Soc. Rev. 2010, 39, 3648-3663.

(9) Zhu, K.; Li, S.; Wang, F.; Huang, F. J. Org. Chem. 2009, 74, $1322-1328$.

(10) Yu, G.; Zhang, Z.; Han, C.; Xue, M.; Zhou, Q.; Huang, F. Chem. Commun. 2012, 48, 2958-2960.

(11) Kang, S. O.; Begum, R. A.; Bowman-James, K. Angew. Chem., Int. Ed. 2006, 45, 7882-7894.

(12) Bowman-James, K. Acc. Chem. Res. 2005, 38, 671-678.

(13) Kubik, S. Chem. Soc. Rev. 2009, 38, 585-605.

(14) Gale, P. A.; Busschaert, N.; Haynes, C. J. E.; Karagiannidis, L. E.; Kirby, I. L. Chem. Soc. Rev. 2014, 43, 205-241.

(15) Mosca, S.; Yu, Y.; Gavette, J. V.; Zhang, K.-D.; Rebek, J. J. J. Am. Chem. Soc. 2015, 137, 14582-14585.

(16) Martí-Centelles, V.; Pandey, M. D.; Burguete, M. I.; Luis, S. V. Chem. Rev. 2015, 115, 8736-8834.

(17) Vilar, R. Angew. Chem., Int. Ed. 2003, 42, 1460-1477. 
(18) Gimeno, N.; Vilar, R. Coord. Chem. Rev. 2006, 250, 3161-3189.

(19) Ramos, S.; Alcalde, E.; Doddi, G.; Mencarelli, P.; Pérez-García, L. J. Org. Chem. 2002, 67, 8463-8668.

(20) Alcalde, E.; Ramos, S.; Pérez-García, L. Org. Lett. 1999, 1, 1035-1038.

(21) Martí-Centelles, V.; Burguete, M. I.; Luis, S. V. Chem.-Eur. J. 2012, 18, 2409-2422.

(22) Martí-Centelles, V.; Burguete, M. I.; Luis, S. V. Sci. World J. 2012, 2012, 748251 DOI: 10.1100/2012/748251.

(23) Martí-Centelles, V.; Burguete, M. I.; Cativiela, C.; Luis, S. V. J. Org. Chem. 2014, 79, 559-570.

(24) Meshcheryakov, D.; Arnaud-Neu, F.; Bohmer, V.; Bolte, M.; Cavaleri, J.; Hubscher-Bruder, V.; Thondorf, I.; Werner, S. Org. Biomol. Chem. 2008, 6, 3244-3255.

(25) Kataev, E. A.; Kolesnikov, G. V.; Arnold, R.; Lavrov, H. V.; Khrustalev, V. N. Chem.-Eur. J. 2013, 19, 3710-3714.

(26) Dabrowa, K.; Niedbala, P.; Majdecki, M.; Duszewski, P.; Jurczak, J. Org. Lett. 2015, 17, 4774-4777.

(27) Evans, N. H.; Serpell, C. J.; Beer, P. D. New J. Chem. 2011, 35, 2047-2053.

(28) Hancock, L. M.; Beer, P. D. Chem.-Eur. J. 2009, 15, 42-44.

(29) Martí-Centelles, V.; Izquierdo, M. A.; Burguete, M. I.; Galindo, F.; Luis, S. V. Chem.-Eur. J. 2014, 20, 7465-7478.

(30) Martí-Centelles, V.; Burguete, M. I.; Galindo, F.; Izquierdo, M. A.; Kumar, D. K.; White, A. J. P.; Luis, S. V.; Vilar, R. J. Org. Chem. 2012, 77, 490.

(31) Becerril, J.; Bolte, M.; Burguete, M. I.; Galindo, F.; GarcíaEspaña, E.; Luis, S. V.; Miravet, J. F. J. Am. Chem. Soc. 2003, 125, 6677-6686.

(32) Megens, R. P.; van den Berg, T. A.; de Bruijn, A. D.; Feringa, B. L.; Roelfes, G. Chem.-Eur. J. 2009, 15, 1723-1733.

(33) Luis, S. V.; Alfonso, I. Acc. Chem. Res. 2014, 47, 112-124.

(34) Feng, W.; Yamato, K.; Yang, L.; Ferguson, J. S.; Zhong, L.; Zou, S.; Yuan, L.; Zeng, X. C.; Gong, B. J. Am. Chem. Soc. 2009, 131, 26292637.

(35) Ferguson, J. S.; Yamato, K.; Liu, R.; He, L.; Zeng, X. C.; Gong, B. Angew. Chem., Int. Ed. 2009, 48, 3150-3154.

(36) Ercolani, G.; Mandolini, L.; Mencarelli, P. Macromolecules 1988, 21, 1241-1246.

(37) The importance of supramolecular interactions at the TS was found in reactions inside molecular containers: Rebek, J. Acc. Chem. Res. 2009, 42, 1660-1668.

(38) In the absence of the templating anion, the formation of insoluble materials hampered our ability to obtain quantitative reaction kinetic data for the whole reaction.

(39) The slow progress of the reaction performed at $1 \mathrm{mM}$ concentration required heating to $40{ }^{\circ} \mathrm{C}$ in order to reach the end of the reaction, as monitored by TLC, in a reasonable time of 1 week.

(40) In the comparison of the results of kinetic experiments with the synthetic results displayed in Table 1 , it is important to note that two different solvents $\left(\mathrm{CDCl}_{3}\right.$ and $\left.\mathrm{CH}_{2} \mathrm{Cl}_{2}\right)$ were used.

(41) Frisch, M. J.; et al. Gaussian 09, revision B.01; Gaussian, Inc.: Wallingford, CT, 2009.

(42) Dolomanov, O. V.; Bourhis, L. J.; Gildea, R. J.; Howard, J. A. K.; Puschmann, H. J. Appl. Crystallogr. 2009, 42, 339-341.

(43) Sheldrick, G. M. Acta Crystallogr., Sect. A: Found. Crystallogr. 2008, A64, 112-122. 